\title{
THE HISTORY OF ISLAM AND ITS DISSEMINATION IN AMBON-LEASE, MALUKU
}

\author{
Hamzah Tualeka Zn \\ IAIN Sunan Ampel, Surabaya - Indonesia
}

\begin{abstract}
Research on the history of Islam and its dissemination on the island of Maluku have hitherto been lacking analytical depth. This paper tries to fill that gap by analysisng four stages in the development of Islam on the Island, referring to approaches to study Islam and Muslims. First, the stage of integration in which Islam tried to incorporate local values and their ramifications. Second, the stage of war and resistance in which the attempts of Islam to become the dominant power on the region face a strong confrontation from the existing power. Third, the stage of reformation and renewal in which Islam interrogates and evaluates itself so as to present itself within the context of Maluku. Fourth, the stage of modern era in which Islam faces challenges not only from other religions mainly Christianity which is equally strong on the island, but also from modernity and its narratives.
\end{abstract}

Keywords: History, the preaching of Islam, Christianity, Ambon-lease.

\section{Introduction}

In his Muqaddimah, Ibn Khaldun speaks of history as a discipline that has a method, aspects and a noble goal. He also asserts that history makes us understand the way earlier nations behave and interact with each other. History makes us know the biographies of the prophets and the state and the wisdom of the kings. So, one may indeed take a lot of lessons from history, and apply its principles and values in his/her everyday life. ${ }^{1}$

\footnotetext{
${ }^{1}$ Ibn Khaldun, Muqaddimah Ibn Khaldun, Translated by Ahmadie Thoha (Jakart: Pustaka Firdaus, 2000), p. 12.
} 
Historically, the preaching of Islam in Indonesia has started since the early advent of this religion in the Archipelago in the seventh century of Christian era, a period which is marked by the active economic and political activities in the centres of Islam especially Baghdad. Islam was brought to the Archipelago by Muslim merchants of mainly Arabic origin, then of Persian and Gujarat nationalities. Centuries later, Indonesian ulamas began to travel to the holy land and other Muslim countries to deepen their knowledge of Islam. However, we don't have at our disposal the names of the early Indonesian scholars prior to the $15^{\text {th }}$ century who learned Islam abroad.

Some points need to mention here. First, the preaching of Islam was carried out not by violence or war. The preaching of Islam takes place peacefully through trade relationships, marriage and pilgrimage. Second, in general, Muslim merchants and early scholars of the Archipelago did not leave behind notes of their activities and lifes. So it makes it quite difficult for us to trace every details of their history. It seems that for them to carry out Islam on the islands was a matter of simple religious obligations, hence no records or notes were needed to report what they were doing. Third, the early couriers of Islam on the island were simple in their life. They were honest and humble so much so that others do not need to know what they were doing. This disorganised way of disseminating Islam brought a negative implication in terms of not leaving behind a clear imprint in their history.

That is why we cannot know with certainty who are the early scholars of Islam on the island and what they were doing. However, according to Abu Ishak al-Makarany Pasy in his Ithar al-Haq, Islam has entered into Peureulak Bandar (now East Aceh) in the year $173 \mathrm{AH}$. Again, he did not mention who these Muslims are. He continued that by the yaer 225 Hijri the number of Muslims in Peureulak have multiplied. And it is from this region that Islam came to other islands including the island of Maluku.

The preaching of Islam gets an important momentum approximately in the yaer $433 \mathrm{AH}$ (1042AD), when the Islamic empire of Samudera Pasai made its influence and power felt in all over the Archipelago. Its first king Maharaja Mahmud Shah (reigned 433-470 $\mathrm{H})$, and his predecessor Sultan Malik-us-Salih (659-688 H) were among the prominent leaders of the kingdom. 


\section{The Preaching of Islam: The Integrative Stage}

The year $650 \mathrm{AD}$ (17 years after the death of the Messenger of Allah SAW) marked the beginning of the introduction of the Archipelago in both the Arab regions -especially Baghdad- and Europe through the trade of cloves. ${ }^{2}$ Since then the commerce between the Archipelago and the Arabs as well as the Persian became intensified. The price of the cloves was very expensive especially in Europe that the ships carrying them will certainly bring a lot of profit. Thus, it is also possible to relate the advent of Islam on the Moluccas island with trade activities in it. ${ }^{3}$

Since Islam came to the island through trade, its dissemination was then carried out peacefully. Social interaction between the indigenous people and the Arab traders as well as the Iranian merchants was the key for the success of Islam. Kings were so quick to convert into the new religion of Islam so much so that the whole regions was subsequently called Jazirah al-Mulk which means islands of kings indicating that the islands were now the dominion of the newly converted kings.

Sufism played a prominent role in the process of Islam becoming the dominant power in the region. In fact the whole Archipelago was interested in Sufism because of its approach and character in its social and religious interaction. Interestingly, because of the Persian presence on the island, Shi'ism was also part of the history of Islam in this particular part of the country. Already, around the year 470 Hijri and 502 Hijri, a group of Shi'i preachers came to the island. Among these preachers -it was said- was the sons of Jafar Sadiq, the grandson of Ali ibn Abi Talib. These preachers were latter to become the ancestors of the four kings of the islands, namely the king of Ternate (Mansur Malamo), of Tidore (Syahadati), of Bacan (Kacil Open) and of Jailolo (Darajati).

In the history of Maluku, the preaching of Islam adorns other nations such as that which has been shown by Sultan Zainal 'Abidin,

\footnotetext{
2 Clove is one herb that is very interesting since the seventh century $\mathrm{AD}$, and the Moluccas is the place to grow your own in the forests and eventually cultivated, planted by the residents regularly. Spices types were very famous in the world market of Europe at that time.

3 Thomas Arnold W, The preaching of Islam, Translated by Nawawi Rambe (Jakarta: Wijaya, 1979), pp. 317-318.
} 
the Sultan of Ternate, as well Sirullah Sultan, the Sultan and the Sultan Khairun Babullah, and Jamaluddin Sultan of Tidore. They have been instrumental in the struggle to defend the people and their religion from the enemies. On 28 February $1570 \mathrm{M}$ tragic events in which the Sultan Khairun and other sultans have been murdered by the Portuguese during the holding of a cooperation agreement. This is a form of treason the governor de Mesquita (Portugal) on a cooperation agreement with the Sultan. When there is the establishment of a party of Christians that have no sin to break a promise if only Muslims. ${ }^{4}$

\section{The Preaching of Islam: The Resistance Stage}

On the one hand we can say that it was because of the cloves that Islam spread in the Maluku, but on the other hand it was also because of other factors mainly the Western presence and colonisation. Apparently, the Western aspiration to take control of the island became the strong drive to colonise not only the island, but also the whole Archipelago. And that stands as the main reason why war against the Western power took place.

The Sabil war (jihäd fi sabil Allah) was the name used by the Muslim Indonesians against the Western power. This war was echoed by various kings and princes in the mid-sixteenth century AD under the leadership of captain-lieutenant of Hatuhaha, Huwamuwal. Hatuhaha Islamic Empire took up arms against the Portuguese army (after the Netherlands), known as Alaka War I and II on the island Haruku, as well as Huwamuwaland Kapaha War in East and Hitu Lei.

History has it that the preaching of Islam in Maluku, especially Ambon-Lease was much characterised by the struggle of indigenous Muslim against the Christian priests and missionaries. ${ }^{5}$ History records that one of the magnifying VOCs named Stevenvan der Haghen pretended to be Muslim, and offered an assistance for Muslims in their fight against the Dutch and the Portuguese, as well as against the Catholic enemies. ${ }^{6}$ This assistance however, was a trick to deceive the Muslims. And as war progressed, Muslims were loosing.

\footnotetext{
${ }^{4}$ Hamka, Sejarah Ummat Islam Jilid IV (Jakarta: Bulan Bintang, 1976), pp. 223-227.

5 Maryam Lestaluhu, Sejarah Perlawanan Masyarakat Islam Terbadap Imperialisme di Daerah Maluku (Bandung: Al-Ma'arif, 1998), p. 41.

6 In principle the request for assistance is approved but must meet several requirements, including VOC should be allowed to build the fort in Ambon, if successfully expelled the Portuguese. Hearing the news that the forces of jihad Hitu
} 
This man and his Dutch allies built a Victoria castle to defend against the Muslims. Making use of the close friendship with the Hitus -who happened to be Muslims themselves- the Dutch began to exercise their power over the weakened Muslims. Slowly but surely, the Islamic Empire on the island started to erode, and the Muslims were forced to embrace Christianity or else they would be killed or expelled from their homeland. ${ }^{7}$

The so-called Christianisation of the people of Ambon as well as the war between the Muslims of the island against the colonising power resulted in the following. First, the Hitu tension which last for 8 decades from 1520 to 1605; an internal tension which have indeed caused the civil war. In fact, the Hitu were loving people. They always showed their love of country and religion. But since the advent of the Portuguese and the Dutch, they turned violent.

Second is an Alaka War I in Hatuhaha, Haruku island in 1570 1605. The battle lasted for 35 years where militias Hatuhaha jihad against the vicar and Portuguese missionaries and colonialists do not capture the whole Hatuhaha Amarima Lounussa, but was forced militias must give up his brother, namely Laisina who fell into the hands of the invaders through persuasion and wiles of the invaders (the agreement will come back to Islam after several months became a Christian, but when the moon promised the authorities that the invaders had passed and Laisina was still on Christianity, then the country or village where he lived was named Hulaliu, which means the country in passes). It's a sobriquet it, because Laisina has reneged on a promise to return in partnership Amarima Laounussa, Islam Hatuhaha. ${ }^{8}$

Third, Alaka Hatuhaha War II which took place between the years 1620 - 1637, where the occupiers have never succeeded. Both the Portuguese and the Dutch were loosing in the war as reported by J.P. Coen. ${ }^{9}$ Fourth, the Banda Banda (Lawataka) wars between 1609 to

VOC then assisted on 23 February 1605 the Portuguese surrendered without resistance to the Dutch (VOC). So then the VOC allowed to set up fort in Uritetu, between Waitomu with Waisilale named Victoria who means victory. Now used as a fortress and military base once used as RMS the Guard in 1950.

7 Ibid., p. 28.

8 Ibid., pp. 3-4.

9 Richard Z. Leirissa, Maluku Dalam Perjuangan Nasional Indonesia, Jakarta: Lembaga Sejarah Fakultas Sastra Indonesia, 1975), p. 22. 
1621. This is the war of the rich and the powerful. Although ultimately must accept the risk to die a martyr in an unequal battle. Here J.P. Coen with great force massacred almost all the people known as the Banda Banda Moord and cutting off almost everything including trees and crops.

Fifth, the Huwamuwal war between 1625 - 1656 (31 years). Muslims in Huamual under the leadership of Sangaji and Gimalaha Luhu also face Dutch troops led by Plamming oods van Hoorn. The Mujahid with a persistent defense of religion and homeland. ${ }^{10}$ Sixth, the Wawane war between 1633 - 1643 (10 years). The push for indigenous Muslims to surrender make them even harder to conquer. Their spirit of jihad never faded. Their homeland and Aqeedah was never mortgaged. ${ }^{11}$

Seventh, Iha war between 1632-1654 (22 years). Muslim paramilitary forces of Amaiha are always victorious in their war. But when van oods Hoom use tactics of deception by utilizing two petuanan Amaiha lieutenant who had been aposted, Sasabone and Toupessy attacked the government center in Ulupalluw Amaiha by firing the bones of pigs to the mosque Baiturrahman and Kedatin Hitu City. ${ }^{12}$ Eight, the Kapahaha war between 1636 - 1646 (10 years). Although the Dutch attack repeatedly, the Muslims were not afraid. The remained insistent in their path.

Nineth, the Hunimoa war in Sirisori otherwise called the War of Pattimura between 1816 to 1817 . When the lands of Saparua which had been Christianized attacked Hunimoa, a son Amaiha led the war against the Dutch with the goal to capture the Castle Stede Duur in Saparua. The Laskar Jihad, by onslaughting the enemies from Waisisil succeeded in destroying the enemy, including killing van der Berg the Saparua resident. Pattimura war is a holy war to defend Islam against its enemies, invaders, Dutch colonialism and imperialism. ${ }^{13}$

Of course, the heroic events of the Muslim people of AmbonLease in the challenges facing the invaders will never be forgotten, in the form of bitter memories of suffering, misery and prolonged trauma. The past of the Muslims in Ambon-Lease is full of grief and

\footnotetext{
10 Ibid.

11 Ibid., pp. 23-24

12 Ibid., pp. 25-26.

13 Ibid., pp. 30-32.
} 
pain, but more real suffering are those who have lost their aqidah, Islam, humanity and the most fundamental human rights namely the right to God.

Indeed, in early times the Dutch presence, not the interests of religion are the main objectives, but politics and economics, the VOC was established in 1605, followed by religious purposes after applied the slogans included in VOCs come in there where the Church was taken along. Cloves and nutmeg has a way to make the nation's history is full range of events for centuries. Historically, cloves and nutmeg also has influence on the introduction of Islam and Christianity and occupiers to the area. For one thing the colonists very profitable, but not least bring misery for the people of the Maluku Ambon-Lease and which are generally embraced Islam. Apparently such applicable law of the jungle, that anyone who in power then he was the one who can determine everything according to his will, he regarded as commonplace, as if at the time of the Portuguese people were forced to embrace Roman Catholicism, then when the Dutch came to power, Muslims were forced to embrace Roman Catholicism. ${ }^{14}$

Based on the above history, it is known that the people of Maluku has long been integrated in the Dutch political system. Since then thousands of Ambonese Christians left home to work on military and civilian agencies across the country. They are used as a Colonial soldier in control of areas that have not conquered the archipelago. The Dutch invasion of Aceh in 1873 was part of the greater plan to capture Ambon and other areas in the country. Citing St. Agustin, Thomas W. Arnold in his The preaching of Islam says that in 15th century many people converted to Christianity simply because of material and temporal reasons. ${ }^{15}$

\footnotetext{
${ }^{14}$ Such things have a bitter history of sculpture for the oppressed people, the Muslims, their possessions, their dignity, their human rights. Not so for his brother how Christians who had converted to Christianity, although Pattimura War history has revealed the existence of compactness and Muslim-Christian cooperation by some people to escape from the oppression of the Dutch in Ambon-Lease earth, but the notion of truth as it is still mired in controversy in among historians.

15 Thomas Arnold W. The Preaching of Islam, Terj. Nawawi Rambe (Jakarta: Wijaya, 1979), p. 368.
} 


\section{The Renewal Period}

After the preaching of Islam during the period of war and resistance, then comes the period of renewal through the forming of religious organisation by the Muslims of Ambon. At a national level, Muhammadiyah was the first organisation to be found.

Muhammadiyah was founded by KH. Ahmad Dahian on 8 Dhu alHijjah 1330 (18 November 1912). It is one of the major Islamic organization in Indonesia. ${ }^{16}$ Muhammadiyah's goal as stated in the articles of Chapter II Article 3 Basic purpose and objective is to uphold the religion of Islam so that the community can realize the truth of Islam. To achieve that goal Muhammadiyah sought charitable efforts in various fields such as economics, education, health, social, legal research or da'wah of Islam and sermons Islamiyah. ${ }^{17}$

The organisation has a women branch called 'Aisyiyah, and youth movement called the Young Muhammadiyah (AMM), apart from the Nasyi'atul 'Aisyiyah, Youth Muhammadiyah, Muhammadiyah Students Association, Muhammadiyah Students Association, scouting movement, HW (Hizbul Wathan) and the health section called PKU (Pembina people's Welfare).

Muhammadiyah slogan is: "A combination of thread forms a clothe." Also the motto of its founder: "Sepi ing pmrih, rame ing gawe". 18 With this motto Muhamrnadiyah becomes successful. Muhammadiyah has made a large contribution in developing the mission of Islam in Indonesia, and in recent years showed greater activity in the entire Archipelago.

Muhammadiyah established a branch in Ambon in 1932, despite challenges and obstacles from the invaders and some communities in Ambon-Lease, but the institution continues to demonstrate his ability to grow. Although its followers at that time are not a lot, the religious activities were done regularly every Thursday night and Friday at the secretariat office. In 1940, it succeeded in forming Scouting Hizbul Wathan. Since the coming of Japan in 1942 and NICA 1945 to RMS in

\footnotetext{
${ }^{16}$ Lothrop Soddard, Dunia Baru Islam (Jakarta: Menko Kesra, 1966).

17 PP Muhammadiyah, Anggaran Dasar Dan Anggaran Rumah Tangga Mubammadiyah (Yogyakarta: PP Muhammadiyah, 1984), p. 5.

18 Sepi ing pamrih, rame ing gawe (Javanese), sepi dalam eksen (much talking), but serious in working and doing, but of course preachers talk more, work more or doing good more.
} 
1950, practically the Muhammadiyah branch of Ambon is not growing, but it does remain existent. Dozens of schools called Permi founded by this organization, which consists of 15 madrasas and some preliminary schools may be found here. In 1972 Muhammadiyah began to grow fast. Autonomous organization within Muhammadiyah were formed, each of which as very active.

Apart from Muhammadiyah, there are also local organisations and educational institutions. Madrassas or Islamic schools established before and after independence both by Muslims and non-Muslims since 1942 can be found here. Madrasah Al-Khairiyah was among the madrasa found by Muslims in 1942. Madrasah Al-Hilal and Tawiri in the city of Ambon by Yayasan Al-Hilal, Nad al-Madrasah alDiniyah'Ulum in Ory, Pelauw, and some other madrasas in various areas in Ambon-Lease are other madrasas also found by Muslims. ${ }^{19}$ Nassara is a madrasa found by non-Muslims with the help of the Dutch. Al-Ershad is among the prominent madrasaa of the Muslims. It should be noted first that the position of Arabs in Indonesia in the period in question cannot be equated with the position of strangers such as China and Europe in general is still a people alien to the people of Indonesia. The Arabs were not only Muslims, so have the factors that led them close to natives, but generally they are originating from Indonesia moms, talking with their mother languages. ${ }^{20}$

The Arab descents founded the missionary organization named Jami'at Khair on June 17, 1905 AD, which later became Al-Ershad. In 1911 AD, three teachers from Arab countries joint Jami'at Khair. They are Shaykh Ahmad Soorkati of Sudan (born in Dunggula, Sudan in 1872), Shaykh Muhammad Talib from Morocco and from Shaykh Muhammad Abdul Hamid Mecca. Soorkati plays a pivotal role in spreading new ideas of Islam in Indonesia.

There are also some figures who have contributed to the Muslim community organizations in founding Al-Ershad (1914). Among them are Shaykh Umar Manggus, Sholeh bin Ubaid, Masyhabi Said bin Salim, Salim ibn Umar Balfs, Harhara and Umar bin Abdullah bin

${ }^{19}$ IAIN also been established in the city of Ambon in 1975, which even experienced penah dynamics and change, but re-active several years later (and still exist until now).

${ }^{20}$ Deliar Noer, Gerakan Modern Islam di Indonesia 1900-1942 (Jakarta: LP3ES, 1995), pp. 68-69. 
Sholeh Nahdi. The latter is a Sudanese-born cleric, studied in Mecca and Medina, was was a top figure in his country of origin.

Al-Ershad is basically the same with Muhammadiyah. Both are based on the Al-Quran and Al-Hadith in the sense of upholding the teachings of the salaf. Thus, Al-Ershad has participated in the development of education and the preaching of Islam in AmbonLease.

Field efforts include education, social and the preaching of Islam. At the inception of this organization intend to gather Indonesian people of Arab descent or those Arabs who have long settled in Indonesia. This organization is widespread and is in the center of the capital city of Jakarta to various cities throughout Indonesia. Many of the Arab origin even have home for their own. They developed the method of preaching Islam through education, hospitals, trade, marriage, in addition to activities in the mosques. Not surprising, that many of them become so rich from their activities.

In the colonial period, mainly during the Dutch, though many of the Arab descents are influential in the field of economy and trade as compared with Chinese ancestry, but the Dutch are more inclined to China as a business partner. This is understandable, because the Chinese have no emotional connection with Islam.

Today Al-Ershad still exist in the community, able to maintain a variety of charitable efforts that it has and able to compete well (Fastabiq al-Khairāt) without the Islamic organizations like Muhammadiyah and NU as well as others. In its activities often intertwined cooperation between Al-Ershad's second major Islamic organization in a variety of issues concerning the construction and development of Muslims in national or regional level, Indonesia.

NU (Nahdhatul Ulama) is perhaps the biggest social and religious organisation in the country. In 1916, Haji Wahab Kiyai establish a madrassa named Nahdlatul Wathan with a large and storied buildings in Surabaya. In the early years Madrasah Nahdlatul Wathan was nurtured by renowned scholars, among others Kyai Haji Mas Mansur $^{21}$, Kiyai Ridwan Abdullah, while the school leader is Kyai Haji

${ }^{21}$ In later Kiyai Haji Mas Mansur was elected chairman of Muhammadiyah branch of Surabaya in 1921, and concurrently became consul for the Regional Chairman of Muhammadiyah Jakarta period 1932-1937, and in the Congress was elected chairman of Muhammadiyah organization founded Kyai Haji Ahmad Dahlan in the period 1937- 
Abdul Kahar (a famous merchant in Surabaya). From here came the idea of establishing NU which was finally found in Surabaya on 31 January 1926.

Founder of NU, KH Hasyim Asy'ari argued that Islamic religious establishment means improving the condition of human. If man is good, what else would be fixed thereof. Jihad means to face the hardships and make sacrifices. ${ }^{22}$ Until now NU has so many pesantren. It has also women branch called Fatayat. In its long journey, NU has experienced the dynamics and changes from religious, social, political and practical reasons. The organisation is very much concerned with the social and religious works by empowering community through education.

Perti (Persatuan Tarbiyah Islamiyah/The Union of Islamic Education) is another Islamic organisation in the country whose branch can be found in the island of Ambon. It is engaged in education and the preaching of Islam. Established on May 20, 1930 in Minangkabau by Sheikh Sulaiman Rasuly, Sheikh Mohammed Jamil Jaho and other scholars of the region, Perti is now one of the largest organisation in the area.

In addition to Perti, Persis (Persatuan Islam/The Unity of Islam) is also an important social and religious organisation. It calls basically for the implement of Islamic laws in society based on the Al-Quran and $\mathrm{Al}-\mathrm{Hadith}$. It was founded by A. Hasan on the initiative of $\mathrm{KH}$. Zamzam on September 17, 1923. Like Muhammadiyah, the movement upholds the teachings of the salaf in Indonesia, through the schools and the magazine (Al-Moslem). Boarding schools were established to support they teaching and ideology.

Apart from those social and religious organisations, Islamic political movements were also part and parcel of Islam in Ambon. Prominent among these political movement is PSII (Partai Syari'ah Islam Indonesia/Islamic Syari'ah Party of Indonesia). It was established in 1911 initially under the name of Syarikat Islamic Trade (SDI) under the leadership of Haji Samanhudi. It changed latter into

1943. See Nadjib Hamid (ed.), KH. Mas Mansur Sapukawat Jawa Timur (Surabaya: Hikmah Press, 2005), p. 13.

22 Abubakar, Sejarah Hidup Kyai Wabid Hasyim dan Karangan Tersiar (Jakarta: Panitia Buku Peringatan Alm. Wahid Hasyim, 1997), p. 80. 
Islamic Sharia (SI), led by Haji Umar, and finally became PSII when it was led by Cokroaminoto.

PSII task was to improve the political, economic, educational and social wellbeing of the Muslims in Indonesia. It has charitable projects such as business-IT, infrastructure-IT, infrastructure business as well as schools, madrassas and Islamic boarding schools. Its youth movement is called PMI (Indonesian Muslim Youth), and the scouting movement called Islamic Syarikat Afdeling Pandu. ${ }^{23}$

Because of the prominent activities of the Dutch, colonial government is very hostile to PSII. Many of its leaders were executed, imprisoned and deposed. At the time, PSII has fought to maintain the continuation of the preaching of Islam directly or indirectly in AmbonLease.

Masyumi (Majlis Shura Muslim Indonesia/Muslim Council of Indonesia) is perhaps the greatest political party in Indonesia at the time. It was established during the Japanese occupation but was dissolved by the Japanese. Its goal is to establish Islamic state by uniting the Islamic forces in the country.

Returning to the issue fate of the backwardness of Muslims in the Dutch colonial era. Whereas, the era of independence of Indonesia in 1945 is a new breath of fresh air and for Muslims in Ambon-Lease to begin to develop. Islamic economy is slowly improving and increasing education. Post-independence Indonesia, Masjumi serves as an Islamic political party that in a short time has grown rapidly so that later became the largest political party in post-independence Indonesia. Masjumi has played an important role in maintaining survival The preaching of Islam in this country.

At the beginning of the New Order some Muslim scholars began to occupy important positions in Ambon-Lease, though not yet dominant. The new post-1970, many of the local (indigenous) are Muslims, occupying strategic positions ranging from Maluku provincial districts equitably rather than dominative. The rapid growth of Islam in politics, education and economic development, it is considered as a threat. Coupled with the presence of immigrants BBM the Islamic religion in general and have the spirit to advance in various fields and

${ }^{23}$ Harry J. Benda. Bulan Sabit dan Matahari Terbit; Islam Indonesia pada Masa Pendudukan Jepang (Jakarta: Pustaka Jaya, 1980), pp. 182-183. 
businesses. When the era of reform led to the strengthening of the Musliminfluence. Then the BBM riots and ethnic cleansing inevitable.

\section{The Preaching of Islam in the Contemporary Period}

Globally, the problems facing Muslims in Ambon-Lease are twofold: first, the challenges posed by the development of science and technology, especially communications and information technology which has brought significant impact on Muslims worldwide. It is inevitable that the era of globalization has the potential to change almost everything in the whole system of our society politically, economically, socially, culturally and even religiously.

In addition, levels of poverty and misery of Muslims are increasing, which opens up the way for other social and religious problems. A variety of social ills or social pathologies such as free sex, drugs, theft, robbery, hold-up, corruption, human rights abuses and the like are due to poverty. These are the fundamental problems of Muslims today, which have the direct threat upon the faith and belief of the Muslims. It appears that -more than anything- the increasing poverty in the country poses more threat to Islam and its adherents. In the face of invasion against social and religious values, and amid the plesant promises offered by hedonistic modern life, Islam is expected to become torches that illuminates the life of humankind.

The preaching of Islam puts forward planning and the right strategy with reference to the Messenger of Allah SAW. Muslim intellectuals formulated concepts and methods of Preaching to young people, adults of various walks of life including people whose level of eduction is low and high. And against the contemporary mentality the preaching of Islam is about "competition to goodness" among Muslims and non-Muslims, which means that Islam expects that its adherents offer what is best for the religion and for themselves.

Actually, what happened in Ambon regarding religious and sectarian conflict is potential to strengthen the faith of Muslims. The conflict itself happened because of misunderstanding between Muslims and Christians especially during the presidential era of Habibie in which it was believed that he plans to Islamise the whole Ambon. When the Christians felt the threat, they rose up against the Muslims in a war-like sectarian conflict. Habibie was the representatation of 
Macassar political Islam better known as BBM, which stands for Bugis Buton Makassar. ${ }^{24}$

Facts prove that the goal is the destruction and massacre of Muslims. Muslims are seen as immigrants and Islam is seen as a foreign religion. ${ }^{25}$ In fact, Islam came before Christianity in this island. And it should be noted that Islam has successfully laid the foundation of culture in Ambon-Lease with Islamic nuance. Islam is far more advance in Ambon-Lease. Islam began to enter into this region since the seventh century, while the sixteenth-century Catholic, Protestant XVII century. So obviously if the lay culture of life and Maluku Ambon-Lease is actually a Muslim. But, unfortunately, there is a history book, deliberately distorted. In the history written by "Dutch", the Arab-Indonesia relations in the early centuries, it is removed. As if Hindus and Chinese first came to Ambon-Lease, the Moluccas, when

${ }^{24}$ If the BBM that their presence in the Islamic country or village, then there is a good start for them, factors Islamiyah their creed, and religious equality is easier for them to mingle with the natives as a landowner-landlord. But if their presence in the country or village are Christian, then it is an initial meeting that is not profitable, because of religious differences. This issue also is one of al-thulu'nya asbab question why the Christians launched a massive effort in the expulsion of the BBM from the AmbonLease. The reality of history and social dynamics shows that the achievements of resplendent people BBM is Islamiah propaganda victory, but once gus is a threat to the domination of the Christians here. It can be said also that, gait and the role of Yusuf Kalla and BJ Habibie in Indonesia national context, which both include the best sons of BBM for the nation and state, but on the other hand, they are really a barrier for the motion and the pace of the struggle of Christians. This has contributed to the social nuances of religious conflict in Ambon-Lease.

25 Europeans who first came to the Moluccas was Portugal (1511). In addition to dredge its natural wealth, they also introduced Christianity. In 1605 the Dutch Protestants who hold Portuguese citadel and expel him. When there is war reforms in Europe, the Dutch Protestant combat and eradicate the Portuguese people are Catholic. Therefore, until the year 1950 the Protestant religion became dominant at Ambon-Lease. Maluku own name actually comes from the Arabic, which is al-Muluk. Naming the nuances of Arabic is due to make a map of the Moluccas is the geography of Arab scholars. But after the Dutch, the word is changed to the Moluccas. In the Moluccas, before the arrival of Europeans, Islam has been growing rapidly, the Islamic empire stand strong, such as Ternate, Tidore. So it is actually not a new religion of Islam in the Moluccas. VII-XI century Maluku very crowded merchants Arabic, Persian and Gujarati. In addition to trade until they are also spreading Islam to the kings of the Moluccas. In the fifteenth century under the influence of the Sultan of Ternate, Tidore and Hitu, Islam is growing rapidly in almost all the islands of the Moluccas. Islam entered the path of peace and coolness, without violence. 
Thomas Arnold in the preaching of Islam explained that the early entry is the Arab nation. ${ }^{26}$

\section{Conclusion}

In connection with the history and development of Islam in Ambon-Lease that have been presented in advance, we can put forward the following conclusion. First, the preaching of Islam during the period of assimilation was about the strategy to convert as much people as possible. And Islam was successful in that regard, given that the number of Muslims during this period was quite significant. Second, during the second period of war, tension was already high between Muslims and the colonising powers. Muslims were forced to fight agaist them to defend themselves and to uphold their faith.

Third, at the time of renewal, the propagation of Islam found new form in which pure Islam is presented in line with the political vision of Islam. Fourth, in the contemporary era, the propagation of Islam dealt with two major problems: first, the general impact of technology and globalization that has the potential to change almost all aspects of human life. Second, the spirit to compete with other global forces especially the Christians. Christians were interested in getting rid of BBM here, but the Muslims are determined to defend themselves.]

\section{Bibliography}

\section{Books and Articles}

Abubakar. Sejarab Hidup Kyai Wabid Hasyim dan Karangan Tersiar. Jakarta: Panitia Buku Peringatan Alm. Wahid Hasyim, 1997.

Al-Suyuthy, Jalaluddin Abdurrahman bin Abi Bakar. Al Jämi' al-Shaghìr, II. Bandung: Al Ma'arif, n.d.

Anshory Ch, Nasruddin. Bangsa Inlander, Potret Kolonialisme di Bumi Nusantara. Yogyakarta: LPiS, 2008.

Arnold, Thomas W. The preaching of Islam, translated Nawawi Rambe. Jakarta: Wijaya, 1979.

Badan Pusat Statistik Kabupaten Maluku Tengah. Maluku Tengah Dalam Angka. 1999.

26 Arnold W., The Preaching, pp. 317-318. 
Benda, Harry J. Bulan Sabit dan Matahari Terbit. Islam Indonesia pada Masa Pendudukan Jepang. Jakarta: Pustaka Jaya, 1980.

Bergh, L.W.C. van den. Hadramaut dan Koloni Arab di Nusantara. Jakarta: INIS, 1989.

Boland, B.J. Pergumulan Islam di Indonesia. Jakarta: Grafiti Pers, 1985.

Enklaar, I.H. Joseph Kam Rasul Maluku. Jakarta: Gunung Mulia, 1980.

Feillard, Andree. NU Vis-a-vis Negara, Pencarian Isi, Bentuk dan Makna. Yogyakarta: LkiS, 1999.

Giddens, Anthony. Perdebatan Klasik dan Kontemporer Mngenai Kelompok, Kekuasaan dan Konflik. Jakarta: Rajawali, 1987.

Hamka, Sejarah Umat Islam. Jakarta: Bulan Bintang, 1976.

Hamid, Nadjib (ed). KH. Mas Mansur Sapukawat Jawa Timur. Surabaya: Hikmah Press, 2005.

Khaldun, Ibn. Muqaddimah Ibn Khaldun, translated Ahmadie Thoha. Jakart: Pustaka Firdaus, 2000.

Koentjaraningrat. Manusia dan Kebudayaan di Indonesia. Jakarta: Djambatan, 1975.

Kuntowijoyo. Dinamika Sejarah Umat Islam Indonesia. Yogyakarta: Salahuddu Press - Pustaka Pelajar, 1985.

Leirissa, Richard Z. Maluku Dalam Perjuangan Nasional Indonesia. Jakarta: Lembaga Sejarah Fakultas Sastra Indonesia, 1975.

Lestaluhu, Maryam. Sejarah Perlawanan Masyarakat Islam Terhadap Imperialisme di Daerah Maluku. Bandung: Al-Ma’arif, 1985.

Noer, Deliar. Gerakan Modern Islam di Indonesia 1900-1942. Jakarta: LP3ES, 1995.

PP Muhammadiyah. Anggaran Dasar Dan Anggaran Rumah Tangga Muhammadiyah. Yogyakarta: PP Muhammadiyah, 1984.

Putuhena, Husni. Misi Kristen dan Penjajahan di Maluku, Gerakan Oikumene dan Penghancuran Islam dari Bumi Siwa Lima. Ambon: Lembaga Kepedulian Muslim Maluku/LKMM, 2000.

Soddard, Lothrop. Dunia Baru Islam. Jakarta: Menko Kesra, 1966.

Tualeka Zn, Hamzah. Penyebaran dan Perkembangan Kristen di AmbonLease. Surabaya: Alpha, 2004. 
Hamzah Tualeka Zn

---------. Elemen-Elemen Pokok The preaching of Islam Jakarta: Bintang Multiware, 2011.

Watt, Montgomery. Islam dan Peradaban Dunia. Pengaruh Islam atas Eropa Abad Pertengahan. Jakarta: Gramedia, 1995. 